\section{The quail's tale}

\section{Julian Lewis}

The Neural Crest.

By Nicole le Douarin.

Cambridge University Press: 1983.

Pp.260. £37.50, $\$ 65$.

THE neural crest is a most peculiar part of the vertebrate embryo. It originates at an early stage from the region where the neural tube pinches off from the rest of the ectoderm. While the neural tube develops into the central nervous system, the cells of the neural crest break loose from the neurectoderm and migrate out to form the neurons and glial cells of the peripheral nervous system. This fact, well known since the last century, encouraged the notion that cells with similar origins differentiate in similar ways, and fitted von Baer's theory of the germ layers. But it soon became apparent that the neural crest breaks all such rules: its cells develop not only into neurons and glia, but also, in the region of the head, into almost every sort of connective tissue. Pigment cells also derive from it, as do several types of endocrine cells.

Apart from their initial location, neural crest cells have only one obvious feature in common: they are all migratory. As in the study of any migrant population, the foremost requirement is a method for marking the cells as they set off on their travels, so that they can be identified subsequently. Nicole Le Douarin's involvement with the neural crest began with the discovery of a marking method based on the grafting of cells from quail embryos into chick embryos, where they can be easily distinguished by the appearance of their nuclei. This simple technical advance opened up for her an Aladdin's cave - or should one say Pandora's box? - of problems for study. What controls the paths of neural crest cell migration? What decides where the cells will halt and settle? When, where and how do the cells become determined for a particular mode of differentiation? Indeed, a whole education in developmental biology could be built around the neural crest, and in exploring the behaviour of its cells one is led into the most diverse fields: from the composition of extracellular matrices to the formation of pigmentation patterns, from the causes of malformations of the face to the biochemistry of neuronal differentiation.

Le Douarin's excellent monograph gives a clear and systematic account of methods for investigating the neural crest, of its migratory properties, and of the development of the various cell types and tissues derived from it. There is a marked emphasis on the findings of Le Douarin's own research group, though the large body of work by other investigators is in general well reviewed. The style inclines more to the careful reporting of facts than to the erection of theories. It is most successful where the facts tell a clear story; less so where there are difficult conceptual problems to be analysed. In particular, I found the discussion of the control of pigmentation patterns somewhat disappointing. But the virtues easily outweigh the defects. The text is a pleasure to read, the illustrations are excellent, and the book has already been practically snatched from my hands for use as a work of reference in the laboratory.

Julian Lewis is a Lecturer in the Department of Anatomy at King's College, University of London.

\section{Healers of the whole}

\section{G. Morris Carstairs}

Shamans, Mystics and Doctors:

A Psychological Inquiry into India and its Healing Traditions.

By Sudhir Kakar.

Knopf: 1982. Pp.306. \$15.

SUDHIR Kakar, the author of this set of descriptions of the practices observed in a series of Indian centres for psychic healing, is well qualified for his task. Kakar completed his basic education in India before going on to further training in psychology and psychoanalysis in West Germany, Austria and the United States. While in America he worked for some years in collaboration with Erik Erikson, a psychoanalyst who has paid particular attention to the parts played by contemporary history and culture in personality formation.

In an earlier work (The Inner World, published in 1978) Kakar showed great skill in portraying the essential elements in the major sacred legends of Hinduism, and went on to indicate how such legends continue to influence the behaviour of Hindu men and women to this day. His present book is concerned with healing, and particularly with the healing of mental and psychosomatic disorders, as practised by a variety of traditional healers in India. The setting and mode of practice of each of these healers are described in turn. The first is an elderly, partially-sighted and quite poor man whose consulting room is a small Moslem tomb in Old Delhi. His patients are also drawn from the very poor yet some of them are brought by their relatives from villages many miles away. There is a striking contrast between the squalor of this old man's surroundings and the dignity with he expounds the teachings of Unani, the ancient Arabic school which has descended from that of the Greeks (or Ionians).

The next centre of mental healing considered by Kakar is emphatically Hindu. This is a temple dedicated to
Hanuman in a village a mile or two off the highway which runs from Agra to Jaipur. Here the treatment is conducted by the spirits of Lord Hanuman and those of a number of subordinate deities, contending with the evil spirits which are believed to have been responsible for the patient's malady. This little temple is thronged especially on Tuesdays and Saturdays when a formal peshi or court hearing takes place - by up to 300 patients and their relatives. Many of the patients become possessed by their attendant evil spirits or by Hanuman himself, or one of his assistants. When this happens the relatives engage in conversation with the spirits and are instructed in what they must do.

Similar descriptions follow of the practices of a series of holy men and of one formidable female Guru, Mata Nirmala Devi, who travels the country placing advertisements in the local newspapers announcing her ability to impart instant self-realization to troubled souls.

Each of the descriptive passages is accompanied by a clear outline of the healers' theoretical accounts of the causes of mental disorders, and their cure. Two particularly interesting chapters are devoted respectively to "Tantra and Tantric Healing" and to an account of Ayurvedic theories of mental disease and its remedy. The former discusses an erotically charged philosophy according to which years of self-discipline can be rewarded by a devotee's becoming aware of his true androgynous identity.

As might be expected of a psychoanalyst, Kakar pauses from time to time to take note of his own reactions (whether of attraction or antipathy) to these healers' often forceful personalities. He readily admits that Western science has tended to dismiss Eastern theories about mental illness as unworthy of serious consideration, and does not exempt himself from this criticism. In his chapter on Ayurveda, for example, he writes: "I could not quite summon the required scientific attitude of combined respect and skeptism, an open-eyed wonder and the beady eye of critical doubt which are essential for any serious inquiry".

This book offers a valuable introduction to some of the many forms of traditional healing in India. It is timely because some teachers of Western medicine have made infections and biochemical disorders the paradigms for every form of illness. In many advanced countries there is a renewed interest in holistic medicine as a necessary complement to scientific medicine. Indian traditional medicine has suffered from its lack of scientific inquiry but some of its teachings (including Ayurveda) have long urged the need to consider each patient's whole being and not merely his presenting symptoms. This is surely good practice in any country.

G. Morris Carstairs was formerly Professor of Psychiatry at the University of Edinburgh. 